\title{
Genetic diversity in Dactylonectria pauciseptata associated with black foot disease in New Zealand
}

\author{
Yu Sheng ${ }^{1}$, Eirian E. Jones ${ }^{1}$ and Hayley J. Ridgway ${ }^{2, *}$ \\ ${ }^{1}$ Faculty of Agriculture and Life Sciences, Lincoln University, PO Box 84, Lincoln 7647, New \\ Zealand. \\ ${ }^{2}$ The New Zealand Institute for Plant \& Food Research Limited, Private Bag 4704, Christchurch \\ 8140, New Zealand \\ ${ }^{*}$ Corresponding author: Hayley.Ridgway@plantandfood.co.nz
}

\begin{abstract}
The fungal genera Ilyonectria and Dactylonectria are causal agents of black foot disease affecting grapevines. A New Zealand survey of grapevines symptomatic for this disease was conducted in 2005, and $11 \mathrm{D}$. pauciseptata isolates were recovered. The incidence of this disease has increased over the last decade so a multi-gene approach was used to accurately identify these isolates and to determine whether they could infect grapevine roots in vitro. Eight of the original $11 \mathrm{D}$. pauciseptata isolates remained viable and were recovered from storage. DNA sequencing, universally primed polymerase chain reaction (UP-PCR) and a detached root assay were used to characterise these eight isolates. Phylogenetic analyses of ITS, $\beta$-tubulin, EF1- $\alpha$ and histone gene regions showed a monophyletic clade using the rRNA gene, EF1- $\alpha$ and histone gene, but paraphyletic based on $\beta$-tubulin. UP-PCR showed genetic diversity, with five major groups $(\mathrm{P}<0.01)$, with major groups concordant with the $\beta$-tubulin phylogeny. Pathogenicity tests with two common rootstocks showed that isolates produced lesions. Two distinct groups of D. pauciseptata were identified. Both groups are capable of infecting grapevine roots.
\end{abstract}

Keywords Black foot, Dactylonectria pauciseptata, grapevine, pathogenicity

\section{INTRODUCTION}

The fungal genera Ilyonectria and Dactylonectria (Lombard et al. 2014) contain species that are known causal agents of black foot disease, which affects grapevines (Vitis spp.) both in nurseries and vineyards throughout the world. Over the last decade, the incidence of this disease has increased significantly in major viticulture regions, including South Africa, New Zealand, Italy, Spain, Portugal, Australia, North America and Brazil (Halleen et al. 2004; Petit \& Gubler 2005; Alaniz et al. 2009; Cabral et al. 2012; Úrbez-Torres et al. 2014; dos Santos et al. 2014). Infected vines typically show a range of decline symptoms, including delayed or absent budding, sparse foliage and small leaves with interveinal chlorosis, slower growth, shortened internodes and necrosis. Dactylonectria pauciseptata (syn. Cylindrocarpon paucisepatum) was first recovered from necrotic regions on roots, wood and trunk bases of infected Vitis spp. rootstocks and dying plants with similar symptoms to black foot disease by Schroers et al. (2008). To date, it has been characterised by morphology, DNA sequencing and pathogenicity assays as a pathogen of grapevine and other hosts in many countries, including Spain, Turkey, Canada, Brazil, and Italy (Martin et al. 2011; Erper et al. 2013; Úrbez-Torres et al. 2014; dos Santos et al. 2014; Aiello et al. 2014). However, it has not been associated with black foot disease in New Zealand and there are no studies describing the 
genetic diversity of this species.

Dactylonectria spp. are difficult to identify and cannot be accurately differentiated by morphological methods alone. The recent work of Cabral et al. (2012) highlighted the need to use the sequence of four gene regions to accurately identify Dactylonectria/Ilyonectria species. In that work, the authors used multi-gene analysis (rRNA, $\beta$-tubulin, translation elongation factor 1- $\alpha$, histone H3) to distinguish New Zealand D. pauciseptata strains from either Slovenian or Portuguese strains. In recent work by ÚrbezTorres et al. (2014) in Canada, a multi-gene analysis was applied to identify five different black foot fungi associated with declining young vines, namely $D$. pauciseptata, I. liriodendri, D. macrodidyma, I. robusta and D. torresensis. However, there has been no analysis of New Zealand isolates using a four-gene phylogeny to identify this species.

In other countries, researchers have studied the pathogenicity of $D$. pauciseptata isolates recovered from woody plants of grapevines and other hosts. In South Africa, four species ("C." destructans, I. liriodendri, D. macrodidyma, D. pauciseptata) recovered from apple roots were able to induce lesion development on seedling roots with variable pathogenicity, except for one isolate of D. pauciseptata (STE-U6630), which did not cause a significant amount of root rot or reduction of weight and height (Tewoldemedhin et al. 2011). In Turkey, Erper et al. (2013) tested the pathogenicity of selected isolates from a group identified as Dactylonectria and Ilyonectria species, including a $D$. pauciseptata isolate from kiwifruit. Results showed that 10 out of 11 isolates, including the isolate of D. pauciseptata, were able to induce typical root-rot disease symptoms, affecting plant development and leading to the death of some kiwifruit plants.

In New Zealand, a national survey in 2005 recovered 174 isolates from symptomatic vines of eight major grape-growing regions. Most of these isolates (95\%) belonged to the D. macrodidyma complex, I. radicicola complex and I. liriodendri (Bleach et al. 2006) and were shown to be causal agents of black foot disease in New Zealand
(Pathrose, 2012). A low frequency $(6.3 \% ; n=11)$ of isolates identified by morphology and $\beta$ tubulin sequences as D. pauciseptata were also isolated during the survey but their genetic diversity and pathogenicity were not assessed. The overall aim of this study was to use a multigene approach to accurately identify these 11 New Zealand isolates and to determine whether they could infect grapevine roots in vitro.

\section{MATERIALS AND METHODS Fungal cultures}

Dactylonectria pauciseptata isolates collected from New Zealand in 2005 were obtained from the Lincoln University culture collection where they had been stored as mycelia plugs in $20 \%$ glycerol at $-80^{\circ} \mathrm{C}$. All isolates were subcultured onto a potato dextrose agar (PDA; Difco) and grown at $20^{\circ} \mathrm{C} 12 \mathrm{~h}$ light:dark conditions for 7 days. Of the original $11 \mathrm{D}$. pauciseptata isolates that had been stored, only eight (Co6g, Mar5a, Hb3b, Mtb1a, Mar14b, Ack2b, Mar6a and Ack2e) remained viable and could be recovered (Table 1). One isolate of I. liriodendri (CO1b) was selected as a positive control from isolates previously demonstrated to be pathogenic on grapevines (Pathrose 2012).

\section{Genomic DNA extraction}

DNA had been extracted each of the 11 isolates using the PureGene DNA extraction kit (Gentra systems, USA) prior to storage. The DNA samples had been stored at $-20^{\circ} \mathrm{C}$. The DNA samples were checked by gel electrophoresis and spectrophotometry and found to still be intact; thus, genetic material for all 11 isolates was available for the current study. The DNA sample of an isolate (AvoC2) from a root lesion on a symptomatic avocado plant was also included in the molecular identification (Table 1). This sample was included because it had been identified by DNA sequencing of the $\beta$-tubulin gene as D. pauciseptata.

\section{Molecular identification}

The identity of all $11 \mathrm{D}$. pauciseptata isolates from grapevine was confirmed by DNA 
Table 1 List of New Zealand Dactylonectria isolates for phylogenetic analysis and pathogenicity studies.

\begin{tabular}{cccc}
\hline Species & Isolate Code & Host & NZ Origin \\
\hline D. pauciseptata & Ack2b & Vitis vinifera & Auckland \\
D. pauciseptata & Ack2e & Vitis vinifera & Auckland \\
D. pauciseptata & CO6g & Vitis vinifera & Central Otago \\
D. pauciseptata & $\mathrm{Hb} 3 \mathrm{~b}$ & Vitis vinifera & Hawkes Bay \\
D. pauciseptata & $\mathrm{Hb} 6 \mathrm{~b}$ & Vitis vinifera & Hawkes Bay \\
D. pauciseptata & Mar5a & Vitis vinifera & Marlborough \\
D. pauciseptata & Mar6a & Vitis vinifera & Marlborough \\
D. pauciseptata & Mar14b & Vitis vinifera & Marlborough \\
D. pauciseptata & Mar17d & Vitis vinifera & Marlborough \\
D. pauciseptata & Mar17e & Vitis vinifera & Marlborough \\
D. pauciseptata & Mtb1a & Vitis vinifera & Martinborough \\
D. pauciseptata & AvoC2 & Persea americana (avocado) & Northland \\
I. liriodendri & CO1b & Vitis vinifera & Central Otago \\
\hline
\end{tabular}

sequencing of four taxonomically informative genes (rRNA, $\beta$-tubulin, translation elongation factor 1- $\alpha$, histone H3) as described by Cabral et al. (2012). The ribosomal DNA was amplified using the universal primers ITS4 and ITS1F (White et al. 1990), the elongation factor 1-a gene using primers EF1 and EF2 (Carbone et al. 1999), the $\beta$-tubulin gene using primers $\mathrm{T} 1$ and Bt $2 b$ (Cabral et al. 2012) and the histone gene using primers CYLH3F and CYLH3A (Crous et al. 2004). The PCR products were sequenced directly at the Lincoln University Sequencing Facility. The sequences were submitted to a blastn search (http://www.ncbi.nlm.nih.gov/BLAST/) to confirm matching species in the GenBank database. The sequences were aligned with closely related species using the CLUSTALW function of Mega software (Version 5.05; Tamura et al. 2011). A phylogenetic tree for each gene was produced using maximum likelihood based on the neighbour-joining method (Saitou \& Nei 1987) and 1000 bootstrap replications.

\section{Genetic diversity}

Genetic diversity was assessed using five UP-PCR primers (Table 2). Each $25 \mu \mathrm{L}$ PCR contained $1 \times$ PCR buffer (Roche Diagnostics, Basel,
Switzerland), $200 \mu \mathrm{M}$ each of dGTP, dCTP, dATP and dTTP), 20 pmol of UP-PCR primer, $2.5 \mathrm{mM}$ $\mathrm{MgCl} 2,1.25 \mathrm{U}$ FastStart Taq DNA polymerase (Roche Diagnostics, Mannheim, Germany) and 20-25 ng template DNA. The PCR program consisted of an initial step of $3 \mathrm{~min}$ at $94^{\circ} \mathrm{C}$, followed by 5 cycles of denaturation at $94^{\circ} \mathrm{C}$ for $30 \mathrm{~s}$, annealing at the appropriate temperature (Table 2) for $30 \mathrm{~s}$, and elongation at $72^{\circ} \mathrm{C}$ for $1 \mathrm{~min}$. The next step was 34 cycles of $94^{\circ} \mathrm{C}$ for $30 \mathrm{~s}$, annealing at the appropriate temperature (Table 2) for $90 \mathrm{~s}$ and $1 \mathrm{~min}$ primer extension at $72^{\circ} \mathrm{C}$. A final extension was performed at $72^{\circ} \mathrm{C}$ for $10 \mathrm{~min}$. All UP-PCR amplification products were separated by $1 \%$ agarose gel electrophoresis. A binomial matrix was generated based on the presence and absence of bands and these data were analysed using Primer software (Version 7.0.5; Primer E Ltd). A resemblance matrix was generated using Jaccard similarity analysis. Analysis of the resultant clusters was done using similarity profiling (SIMPROF) to determine which isolates were significantly different $(\mathrm{P}<0.01)$ from each other (Clarke \& Ainsworth 1993). 
Table 2 Nucleotide sequence and respective annealing temperatures of the UP-PCR primers.

\begin{tabular}{lccl}
\hline Primer Name & \multicolumn{1}{c}{ Primer Sequence } & $\begin{array}{c}\text { Annealing } \\
\text { Temperature }\left({ }^{\circ} \mathrm{C}\right)\end{array}$ & \multicolumn{1}{c}{ Reference } \\
\hline AA2M2 & 5'CTGCGACCCAGAGCGG3' & 50 & Lübeck et al. 1998 \\
AS15 & 5'GGCTAAGCGGTCGTTAC3' & 55 & Bulat et al. 1998 \\
AS15 Inv & 5'CATTGCTGGCGAATCGG3' & 52 & Cumagun et al. 2000 \\
L15/AS19 & 5'GAGGGTGGCGGCTAG3' & 52 & Lübeck et al. 1998 \\
3-2 & 5'TAAGGGCGGTGCCAGT3' & 52 & Bulat et al. 1998 \\
\hline
\end{tabular}

\section{Detached root assays}

Pathogenicity assays were carried out as described by Pathrose et al. (2010) on detached roots of either Vitis vinifera var. 'Schwarzmann' or Vitis vinifera var. 'Riparia Gloire'. A mycelial plug from each of the eight $D$. pauciseptata (Co6g, Mar5a, Hb3b, Mtb1a, Mar14b, Ack2b, Mar6a and Ack2e) isolates and one isolate of I. liriodendri (CO1b) as a positive control were taken from the edge of a colony grown on $1 / 2$ PDA for $7 \mathrm{~d}$ at $20^{\circ} \mathrm{C}$ under 12:12 h dark:light conditions. Young feeder roots of similar age, diameter (1.5-2.0 $\mathrm{mm}$ ) and pigmentation were randomly selected from one-year-old rootstock plants from both cultivars and washed with tap water to remove soil. They were cut into 6-cm lengths. A mycelial plug infested with a fungal colony was placed on the cut end of detached root with the other end placed in a $1.75-\mathrm{mL}$ tube filled with sterile water. Negative controls were inoculated with a disc of uninoculated $1 / 2$ PDA. Eight replicates for each isolate were incubated on moist sterile sand at room temperature arranged in a completely randomised design without light for 4 weeks on rootstock 'Schwarzmann' and both 4 and 8 weeks on rootstock 'Riparia Gloire'. Measurement of lesion length using a digital calliper (Mitutoyo, U.K Ltd) was done after each incubation period. Visual observations were made on the type/ colour of any lesions which developed on the inoculated roots by eye and under the stereo microscope. The lesion length data were analysed by analysis of variance (ANOVA) using Genstat software (Version 16), with significant differences between treatment means determined using Fisher's protected least significant difference
(LSD) (Baskarathevan et al. 2012). To complete Koch's postulates (Agrios 2005), infected roots were surface sterilised and $0.3-\mathrm{cm}$ lengths of roots at $0,0.5$ and $1.5 \mathrm{~cm}$ from the lesion margin were taken and placed separately onto PDA plates amended with chloramphenicol. The plates were incubated at $20^{\circ} \mathrm{C}$ under $12: 12 \mathrm{~h}$ dark:light growing conditions for 1 week before any colonies growing from the roots were identified based on colony and conidial morphology.

\section{RESULTS}

Molecular identification using four taxonomically informative genes

Comparison of ITS, $\beta$-tubulin, EF1- $\alpha$ and histone genes among all $11 \mathrm{D}$. pauciseptata isolates showed that they were $99-100 \%$ identical to each other. These sequences were also compared with data present in the GenBank database from previously sequenced isolates (GenBank accession numbers: JF735307 for isolate Cy238 from Portugal, EF607067, JF735582 and JF735771 for isolate CBS100819 from New Zealand, JF735775 for isolate CBS120171 from Slovenia, and JF735434 for isolate Cy217 from Portugal). All of the GenBank isolates used for comparison had been cited in the taxonomy work of Cabral et al. (2012) as Cylindrocarpon paucisepatum. The ITS, translation elongation factor $1-\alpha$ and histone $\mathrm{H} 3$ neighbour-joining (NJ) trees each contained a single clade of $D$. pauciseptata isolates. The NJ tree generated from $\beta$-tubulin sequences placed the 11 isolates into two clades (Fig. 1). The first clade contained seven isolates and was moderately supported (64\%). The isolate recovered from a symptomatic avocado plant was also placed into 


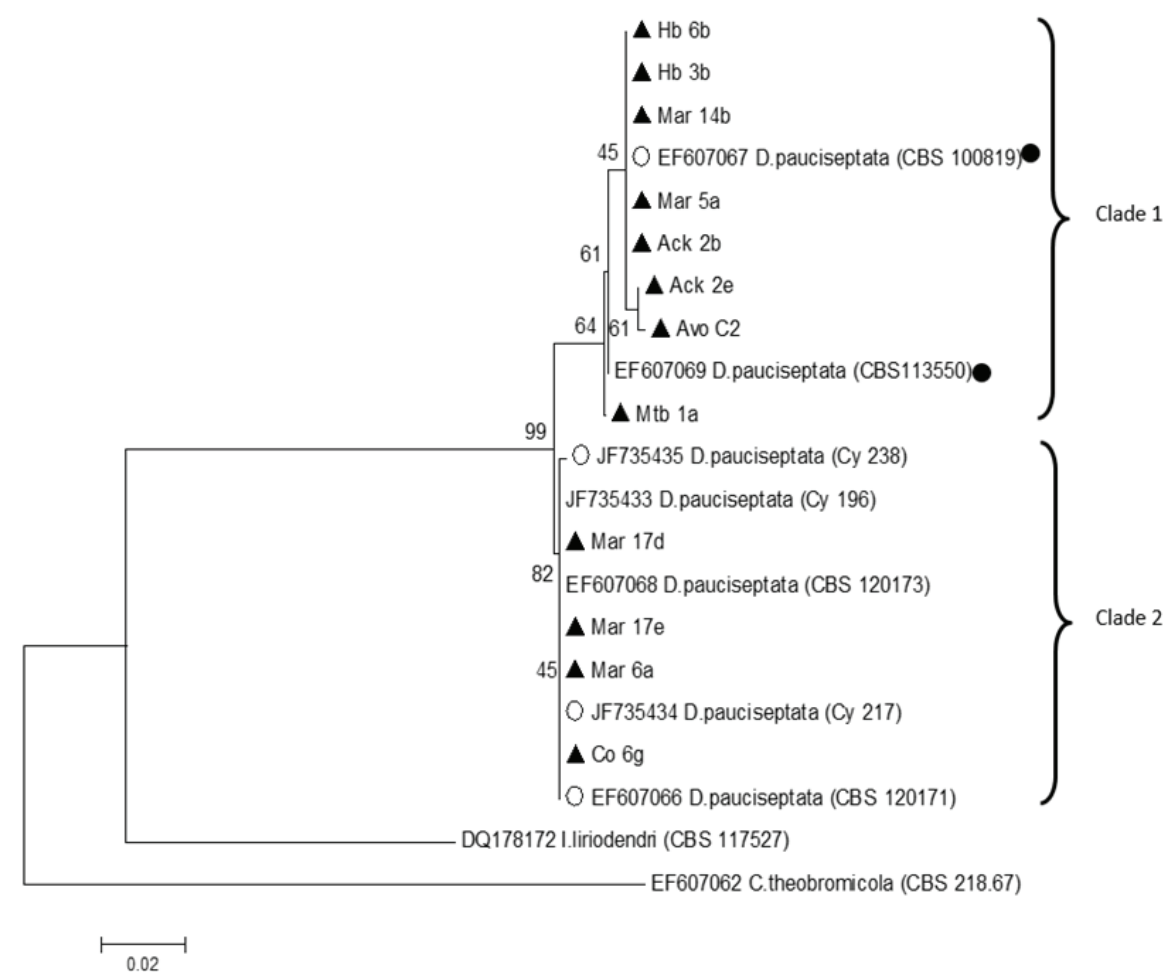

Figure 1 The neighbour joining tree with 1000 replicates of bootstrap values generated by Kimura 2-parameter model of MEGA 5.05 using $\beta$-tubulin sequences of Dactylonectria pauciseptata isolates from New Zealand vineyards and from GenBank with accession numbers. Isolates with a white circle at left side are from voucher specimens identified using the $\beta$-tubulin gene. Isolates: JF735435 - Portugal, JF735433 - Portugal, EF607068 - Slovenia, JF735434 - Portugal, EF607066 - Slovenia. Isolates highlighted with a black triangle represent New Zealand Dactylonectria pauciseptata isolates from the present study. Isolates followed by a black circle are previously published New Zealand strains.

clade 1 and clustered with Ack2e in a sub-group (61\% bootstrap value). This sub-group contained 1 bp substitution from the other five isolates in clade 1. Isolate Mtbla was distinct from the other seven isolates in clade 1. DNA from two $D$. pauciseptata voucher isolates (CBS100819 from Erica melanthera and CBS113550 from Vitis sp.) previously collected from New Zealand (Schroers et al. 2008) were also placed in this clade. The second clade (Mar17d, Mar17e, Mar6a, Co6g) was highly supported (82\%) and clustered with five $D$. pauciseptata sequences obtained from GenBank, including the voucher isolates Cy238 and Cy217 from Portugal, and CBS120171 from
Slovenia. The isolates in clade 1 had nine single base-pair substitutions compared with isolates in clade 2. Colleototrichum theobromicola and I. liriodendri were used as outgroups.

\section{Genetic diversity}

A total of 65 scorable bands were generated by five primers, of which $46 \%$ were polymorphic. Analysis of similarity using the Jaccard similarity index (Baskarathevan et al. 2012) produced a dendrogram with five significantly different groups $(\mathrm{P}<0.01)$ (Fig. 2). Isolates Ack2b, Ack2e, Mar14b, Mar5a, Hb3b and Hb6b formed a single group of six isolates. Mar17d and Mar17e formed 


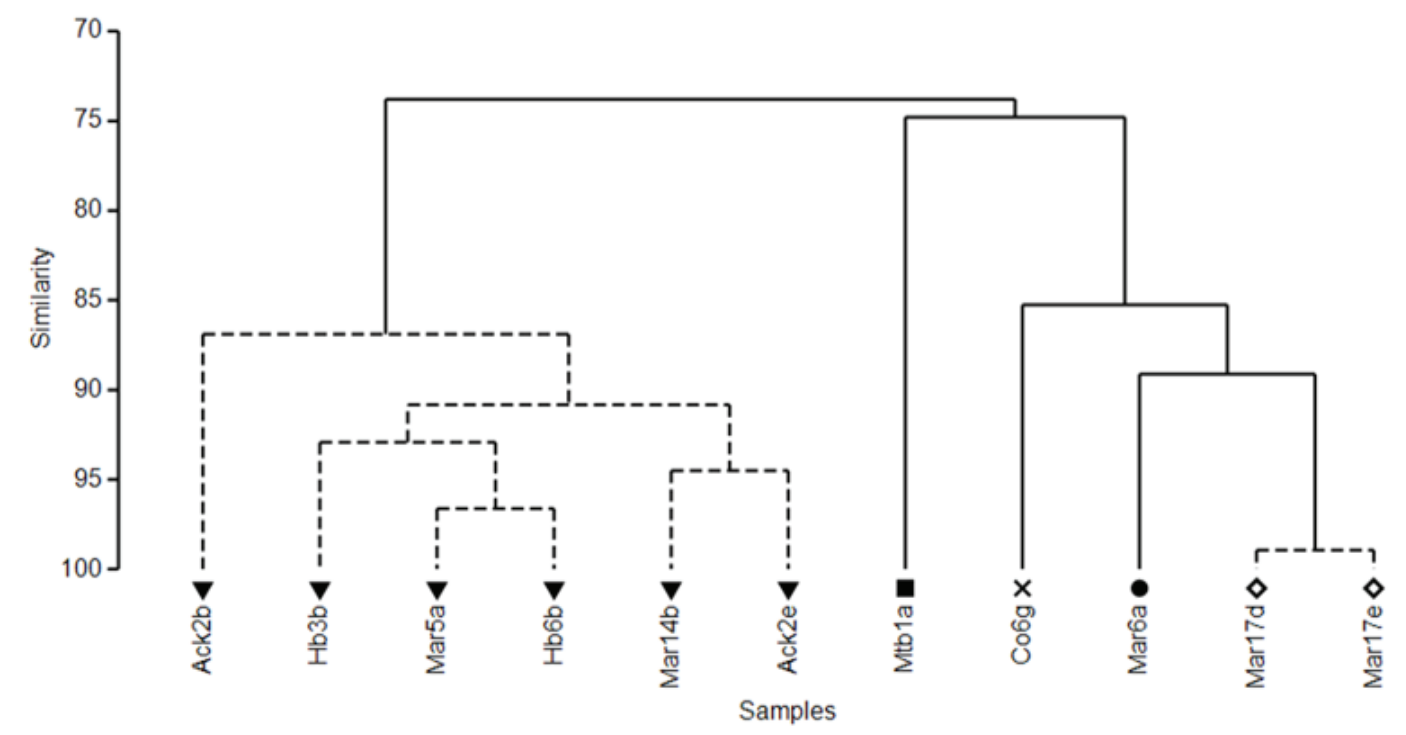

Figure 2 Dendrogram of five significantly different groups $(\mathrm{P}<0.01)$ labelled with different shapes above isolates name produced by the analysis of similarity using the Jaccard similarity index. Groups connected by horizontal unbroken lines are significantly different at $\mathrm{P}<0.01$, with those connected by horizontal broken lines not significantly different.

a group of two isolates and the remaining three isolates were each placed on separate branches. These clusters showed similar trends in isolate groupings as the distinction of isolates shown by the $\beta$-tubulin NJ tree.

\section{Detached root assay}

For both Vitis vinifera 'Schwarzmann' and 'Riparia Gloire' rootstocks, the roots inoculated with D. pauciseptata showed black discolouration as typical infection symptoms at 4 - and 8-week assessment times.

For rootstock Schwarzmann, D. pauciseptata isolates CO6g and Mar14b produced lesions (14.7 $\mathrm{mm}$ and $13.9 \mathrm{~mm}$, respectively) that were significantly different from the uninoculated control $(\mathrm{P}<0.001)$. The remaining six isolates of D. pauciseptata were not significantly different from the control (Table 3). The virulence of the D. pauciseptata isolates within and between each genetic group generated by UP-PCR was variable. The positive control COlb (I. liriodendri) produced the largest mean lesion overall $(36.4 \mathrm{~mm})$. Dactylonectria species were not re-isolated from control roots as observed by colony morphology of any fungi emerging from the root pieces.

For 'Riparia Gloire' (Table 3), the positive control I. liriodendri $\mathrm{CO} 1 \mathrm{~b}$ and D. pauciseptata isolates Ack2e and Mtb1a were pathogenic. Lesions of $12.5 \mathrm{~mm}, 9.1 \mathrm{~mm}$ and $14.5 \mathrm{~mm}$, respectively $(\mathrm{P}=0.012)$ were produced at the 4 -week assessment time. At 8 weeks after inoculation, the positive control I. liriodendri CO1b $(23.0 \mathrm{~mm})$ and D. pauciseptata isolates $\mathrm{Hb} 3 \mathrm{~b}(18.6 \mathrm{~mm})$ and Mar14b $(24.0 \mathrm{~mm})$ produced the longest lesions but these were not significantly different from isolates Mtb1a, Ack2e and Mar5a.

\section{DISCUSSION}

A multi-gene sequence analysis was applied to accurately identify $6.3 \%$ of the isolates recovered during a nationwide survey of symptomatic vines that had been tentatively identified as $D$. pauciseptata using morphology and $\beta$-tubulin sequences. The 11 isolates formed a monophyletic unit in the rRNA gene, EF1- \pm and histone gene tree, while they were paraphyletic based on 
Table 3 Mean lesion lengths ( $\mathrm{mm}$ ) produced on detached roots of Vitis vinifera rootstocks 'Schwarzmann' and 'Riparia Gloire' at various times after inoculation. Ilyonectria liriodendri (CO1b) is included as a positive control.

\begin{tabular}{|c|c|c|c|c|}
\hline \multirow{3}{*}{ Species } & \multirow{3}{*}{ Isolate } & \multicolumn{3}{|c|}{ Mean lesion length (mm) } \\
\hline & & \multirow{2}{*}{$\begin{array}{c}\text { Schwarzmann } \\
4 \text { weeks }\end{array}$} & \multicolumn{2}{|c|}{ Riparia Gloire } \\
\hline & & & 4 weeks & 8 weeks \\
\hline I. liriodendri & $\mathrm{CO} 1 \mathrm{~b}$ & $36.4 c$ & $12.5 \mathrm{~cd}$ & $23.0 \mathrm{c}$ \\
\hline \multirow[t]{11}{*}{ D. pauciseptata } & Mar6a & $0.2 \mathrm{a}$ & $2.2 \mathrm{ab}$ & $2.3 \mathrm{ab}$ \\
\hline & Mtbla & $3.6 \mathrm{a}$ & $14.5 \mathrm{~d}$ & $15.2 \mathrm{abc}$ \\
\hline & CO6g & $14.7 \mathrm{~b}$ & $2.0 \mathrm{ab}$ & $3.2 \mathrm{ab}$ \\
\hline & Ack $2 \mathrm{e}$ & $0.5 \mathrm{a}$ & $9.1 \mathrm{bcd}$ & $16.8 \mathrm{abc}$ \\
\hline & Ack $2 b$ & $1.6 \mathrm{a}$ & $4.3 \mathrm{ab}$ & $5.2 \mathrm{ab}$ \\
\hline & Mar5a & $2.0 \mathrm{a}$ & $3.1 \mathrm{ab}$ & $8.7 \mathrm{abc}$ \\
\hline & $\mathrm{Hb} 3 \mathrm{~b}$ & $3.8 \mathrm{a}$ & $6.6 \mathrm{abcd}$ & $18.6 \mathrm{bc}$ \\
\hline & Mar14b & $13.9 \mathrm{~b}$ & $6.2 \mathrm{abc}$ & $24.0 \mathrm{c}$ \\
\hline & Control & $0.9 \mathrm{a}$ & $0.7 \mathrm{a}$ & $1.1 \mathrm{a}$ \\
\hline & ${ }^{*} \mathrm{LSD}$ & 9.74 & 8.11 & 16.38 \\
\hline & $P$ value & $<0.001$ & 0.012 & 0.028 \\
\hline
\end{tabular}

${ }^{\star}$ Fisher's protected LSD test $(\mathrm{P}<0.05)$.

$\beta$-tubulin phylogenies. For the NJ tree generated from $\beta$-tubulin sequences, eight isolates, including an avocado isolate, were identical to the New Zealand isolates recovered previously from voucher specimens of Erica melanthera (CBS100819) and Vitis spp. (CBS113550), but did not group with voucher isolates from other countries. There were nine bp differences between these eight isolates and the other four isolates which had grouped with international voucher specimens in clade 2. Isolate Mtbla was consistently located on a separate branch from other isolates on the $\mathrm{NJ}$ trees based on sequences of the $\beta$-tubulin and EF1- $\alpha$ gene. It would be interesting to determine if isolates with the distinct $\beta$-tubulin gene sequence are only been found in New Zealand, however, a greater number of isolates from more hosts would be required to do this.

The Dactylonectria/Ilyonectria genus is a complex group which has undergone several reclassifications over the last decade (AgustíBrisach \& Armengol 2013). The taxonomy of the genus Ilyonectria and other black foot pathogens has been modified very recently (Lombard et al. 2014). A new genus, Dactylonectria, with 10 new combinations, several of which were previously treated in Ilyonectria, was introduced from this work. Future studies of this genus using molecular tools may clarify any possible intraor interspecific variation within D. pauciseptata strains. Analysis of these 11 isolates of $D$. pauciseptata showed that they were genetically diverse in New Zealand. When compared to the results for other grapevine pathogens, this result is more polymorphic than the results for Phaeomoniella chlamydospora obtained by Pottinger et al. (2002) but similar to those of Pathrose (2012) for other Dactylonectria species and Baskarathevan et al. (2012) for botryosphariaceous species. The total number of isolates collected in the survey was small and analysis of a greater number of isolates could help determine the relative frequency of members of each of the genetic groups.

Pathogenicity tests on detached roots in comparison with a representative isolate of $I$. liriodendri indicated that $D$. pauciseptata was 
pathogenic towards grapevines with lesions apparent in detached root material. The lesion length of $D$. pauciseptata on detached roots was generally smaller in comparison with the positive control and there was no correlation between genetic groups and pathogenicity. Thus, D. pauciseptata may be less pathogenic than other Dactlyonectria species. Deliberate co-inoculation of $D$. pauciseptata isolates with other Dactylonectria spp. may also be valuable to try in the future work to determine if they are synergistic with other pathogens. Further work on whole plants is also warranted. Dactylonectria pauciseptata may also be more aggressive on hosts other than grapevines, such as avocado. A survey of more hosts with symptoms characteristic of black foot is required to clarify relative pathogenicity on different hosts.

In summary, this study has shown that $D$. pauciseptata is present as at least two genetic groups, one of which appeared unique to New Zealand and potentially deserving of reclassification. There was no apparent difference in pathogenicity between the two genetic groups although different isolates were variable in their pathogenicity on the two rootstocks tested.

\section{REFERENCES}

Agrios GN 2005. Plant Pathology, fifth edition. Elsevier Academic Press Publication, London, UK. 922 p.

Agustí-Brisach C, Armengol J 2013. Black-foot disease of grapevine: an update on taxonomy, epidemiology and management strategies. Phytopathologia Mediterranea 52: 245-261.

Aiello D, Guarnaccia V, Epifani F, Perrone G, Polizzi G 2014. 'Cylindrocarpon' and Ilyonectria species causing root and crown rot disease of potted Laurustinus plants in Italy. Journal of Phytopathology https://doi. org/10.1111/jph.12306.

Alaniz S, Armengol J, León M, García-Jiménez J Abad-Campos P 2009. Analysis of genetic and virulence diversity of Cylindrocarpon liriodendri and C. macrodidymum associated with black foot disease of grapevine. Mycological Research 113: 16-23.
Baskarathevan J, Jaspers MV, Jones EE, Cruickshank R, Ridgway HJ 2012. Genetic and pathogenicity diversity of Neofusicoccum parvum in New Zealand vineyards. Fungal Biology 116: 276-288.

Bleach MC, Jones EE, Jaspers MV 2006. Survey for black foot decline in New Zealand vineyards. Paper presented at the Proceedings of the 4th Australasian Soil borne Diseases Symposium.

Bulat SA, Lubeck M, Mironenko N, Jensen DF, Lubeck PF 1998. UP-PCR analysis and ITS1 ribotyping of strains of Trichoderma and Gliocladium. Mycological Research 102: 933943.

Cabral A, Groenewald ZJ, Rego C, Oliveira H, Crous WP 2012. Cylindrocarpon root rot: multi-gene analysis reveals novel species within the Ilyonectria radicicola species complex. Mycological Progress 11: 655-688.

Carbone I, Anderson JB, Kohn LM 1999. Patterns of descent in clonal lineages and their multilocus fingerprints are resolved with combined gene genealogies. Evolution 53: 11-21.

Clarke KR, Ainsworth M 1993. A method of linking multivariate community structure to environmental variables. Marine Ecology Progress Series 92: 205-219.

Crous PW, Groenewald JZ, Risede JM, HywelJones NL 2004. Calonectria species and their Cylindrocladium anamorphs: species with sphaeropedunculate vesicles. Studies in Mycology 50: 415-429.

Cumagen CJR, Hockenhull J, Lubeck M 2000. Characterization of Trichoderma isolates from Philippine rice fields by UP-PCR and rDNA-ITS1 analysis: identification of UPPCR markers. Journal of PhytopathologyPhytopathologische Zeitschrift 148: 109-115. dos Santos RF, Blume E, Muniz MFB, Steckling SM, Burtet GW 2014. First report of "Cylindrocarpon" pauciseptatum associated with black foot disease of grapevine in Brazil. Plant Disease 98: 567.

Erper I, Agustí-Brisach C, Tunali B, Armengol J 2013. Characterization of root rot disease of kiwifruit in the Black Sea region of Turkey. 
European Journal of Plant Pathology 136: 291-300.

Halleen F, Schroers HJ, Groenewald JZ, Crous PW 2004. Novel species of Cylindrocarpon (Neonectria) and Campylocarpon gen. nov. associated with black foot disease of grapevines (Vitis spp.). Studies in Mycology 50: 431-455.

Lombard L, Van Der Merwe NA, Groenewald JL, Crous PW 2014. Lineages in Nectriaceae: reevaluating the generic status of Ilyonectria and allied genera. Phytopathologia Mediterranea 53: 515-532.

Lübeck PS, Alekhina IA, Lübeck M, Bulat SA 1998. UP-PCR genotyping and rDNA analysis of Ascochyta pisi Lib. Journal of Phytopathology 146: 51-5.

Martin MT, Martin L, Cuesta MJ, GarcíaBenavides P 2011. First report of Cylindrocarpon pauciseptatum associated with grapevine decline from Castilla y León, Spain. Plant Disease 95: 361.

Pathrose B 2012. Characterising sub-species variation in New Zealand Cylindrocarpon species that cause black foot of grapevines. $\mathrm{PhD}$ thesis, Lincoln University, New Zealand.

Pathrose B, Jones EE, Jaspers MV, Ridgway HJ 2010. Development of a grapevine detached root assay for assessing pathogenicity of Cylindrocarpon spp. New Zealand Plant Protection 63: 24-7.

Petit E, Gubler WD 2005. Characterization of Cylindrocarpon species, the cause of black foot disease of grapevine in California. Plant Disease 89: 1051-1059.

Pottinger B, Stewart A, Carpenter M, Ridgway HJ 2002. Low genetic variation detected in New Zealand populations of Phaeomoniella chlamydospora.

Phytopathologia

Mediterranea 41: 199-211.

Saitou N, Nei M 1987. The neighbour-joining method: A new method for reconstructing phylogenetic trees. Molecular Biology and Evolution 4: 406-425.

Schroers HJ, Zerjav M, Munda A, Halleen F, Crous PW 2008. Cylindrocarpon pauciseptatum sp. nov., with notes on Cylindrocarpon species with wide, predominantly 3-septate macroconidia. Mycological Research 112: 82-92.

Tamura K, Peterson D, Peterson N, Stecher G, Nei M, Kumar S 2011. MEGA5: Molecular evolutionary genetics analysis using maximum likelihood, evolutionary distance, and maximum parsimony methods. Molecular Biology and Evolution 28: 27312739.

Tewoldemedhin YT, Mazzola M, Mostert L, McLeod A 2011. Cylindrocarpon species associated with apple tree roots in South Africa and their quantification using realtime PCR. European Journal of Plant Pathology 129: 637-651.

Úrbez-Torres JR, Haag P, Bowen P, O'Gorman DT 2014. Grapevine trunk diseases in British Columbia: incidence and characterization of the fungal pathogens associated with black foot disease of grapevine. Plant Disease 98: 456-468.

White TJ, Bruns T, Lee S, Taylor J 1990. Amplification and direct sequencing of fungal ribosomal RNA genes for phylogenetics. In: Innis MA, Gelfand DH, Sninsky JJ, White TJ, eds. PCR Protocols: A Guide to Methods and Applications. Academic Press, New York, USA. Pp. 315-322. 